M.

\title{
IRON-ZINC SUPPLEMENTATION AMONG ADOLESCENT GIRLS AT ELEMENTARY SCHOOL IN KUPANG CITY, EAST TIMOR PROVINCE.
}

\author{
Yustina Anie Indriastuti Kurniawan ${ }^{1 *}$ dan Siti Muslimatun ${ }^{2}$ \\ ${ }^{1}$ Direktorat Gizi Masyarakat,Departemen Kesehatan RI \\ ${ }^{2}$ Southeast Asian Ministers of Education Organization (SEAMEO) Tropical Medicine (TROPMED) \\ and Public Health Network Regional Center for Community Nutrition (RCCN), UI
}

\begin{abstract}
Anemia is the main micronutrient deficiency problem among adolescent girls in Indonesia. Anemia due to iron deficiency often coexists with zinc deficiency. Both iron deficiency anemia and zinc deficiency can increase the risk of obstetric complications among pregnant women i.e. bleeding during labor and post-partum hemorrhage. Iron-folate supplementation among pregnant women had been conducting since long time ago throughout this country; however, effort to improve the nutritional status particularly among adolescent girls prior to pregnancy is still lack behind. Iron and zinc have antagonistic interaction. Therefore it was challenging to alleviate anemia problem among adolescent girls with appropriate ratio of iron-zinc supplementation, and will give a benefit to improve their nutritional status. This study was aimed to investigate the different ratios of ironzinc supplementation on reducing the prevalence of anemia as improving the nutritional status of adolescent school girls.A female elementary school students age 10-12 years old $(n=137)$ were screened in rural area of Kupang City, East Timor Province. Subjects were assigned randomly to one of the three groups for daily iron-zinc supplementation for 12 weeks; Group 1 (iron; 60 $\mathrm{mg} /$ day), Group 2 (iron and zinc; $30 \mathrm{mg}$ and $15 \mathrm{mg} / \mathrm{day}$ ), Group 3 (iron and zinc; $60 \mathrm{mg}$ and 15 $\mathrm{mg} /$ day). Hemoglobin concentration was measured by cyanmethemoglobin method (Hemocue) to determine the prevalence of anemia ( $\mathrm{Hb}$ level $<120 \mathrm{~g} / \mathrm{L}$ ), while anthropometric assessment was conducted for measuring weight and height to determine the nutritional status. General characteristics was assessed through interview. At base line, $29.1 \%$ of subjects suffered from anemia and in general, the prevalence was reduced to around $13.1 \%$ after they took iron supplements with or without zinc. Hemoglobin concentration was significantly increased among all subjects euther suffered from anemia or not. The result of this study showed that subject who received iron/zinc supplement with ratio 4: 1 for 12 weeks asa "blanket approach" significantly increased hemoglobin conc. higher than to who received iron alone. Similar result occurred when supplement was received to anemic adolescent. Although there were significantly increased of weight, height and BMl for age among all groups, the percentage of subjects were underweight, stunted and wasted remains high after supplementation that $54.6 \%, 36.9 \%$ and $39.2 \%$ respectively. Anemia seems to be a health problem among adolescent school girls in Kupang City, East Timor Province and iron-zinc supplementation with appropriate ratio is promising to increase hemoglobin level. A large scale of cohort study was recommended for female student, to investigate the effect iron/zinc supplementation with ratio 2: 1 on iron, zinc status and growth performance among adolescent girls.
\end{abstract}

Key Words: Iron, Zinc, Adolescent, Girls

\section{PENDAHULUAN}

Anemia masih merupakan masalah utama kurang zat gizi mikro pada remaja putri di Indonesia. Survei Kesehatan Rumah
Tangga (SKRT) menunjukkan bahwa 30 persen remaja putri (10-19 tahun $)^{(1)}$ menderita anemia. Data ini tidak jauh berbeda dengan penelitian penelitian lain yang menunjukkan prevalensi anemia pada 
M.

remaja putri antara 22 persen sampai 44 persen $^{(2,3,4,5,6,7)}$, menunjukkan bahwa anemia merupakan masalah kesehatan masyarakat di Indonesia. Menurut WHO anemia dinyatakan sebagai masalah kesehatan masyarakat, bila prevalensi lebih dari 5 persen $^{(8)}$ Anemia kurang zat besi sering terjadi bersama kurang seng, dimana keduanya dapat meningkatkan risiko ibu hamil mengalami komplikasi. Anemia pada kehamilan, khususnya pada kehamilan remaja berhubungan dengan tingginya angka kematian ibu dan perinatal serta keguguran, Bayi Lahir dengan Berat Badan Rendah (BBLR). Data pengamatan Audit Maternal Perinatal dibeberapa rumah sakit pada tahun 1995, menunjukkan bahwa 40 persen dari kematian ibu disebabkan perdarahan pada waktu persalinan, dimana anemia menjadi faktor yang mendasari ${ }^{(9)}$. Sedangkan kurang zinc meningkatkan risiko terjadinya perdarahan setelah melahirkan karena "atonia uteri"dan cacat bawaan seperti bibir sumbing ${ }^{(10)}$

Remaja putri, terutama didaerah pedesaan juga menderita Kurang Energi Kronik (KEK). Survei Sosial Ekonomi Nasional (Susenas) 1999, menunjukkan bahwa 14,2 persen Wanita Usia Subur (WUS usia 15 - 49 tahun) dan 27,6 persen ibu hamil risiko menderita $\mathrm{KEK}^{(11)}$, dimana ukuran Lingkar Lengan Kiri Atas (LILA) < 23,5 cm. Berapa penelitian menunjukkan bahwa prevalensi KEK (IMT $\left.\leq 18,5 \mathrm{~kg} / \mathrm{m}^{2}\right)$ pada remaja putri bervariasi antara $31-41,2$ persen $^{(3,4,5,6,12)}$. Kecukupan gizi sangat diperlukan oleh remaja putri, sebagai calon ibu harus dijaga status gizi dan kesehatannya agar dapat melahirkan bayi yang sehat. Kebutuhan zat gizi karbohidrat, protein, lemak, vitamin dan mineral meningkat pada masa remaja untuk pertumbuhan fisik dan perkembangan serta untuk aktivitas yang memerlukan energi (olahraga). Pada kondisi khusus seperti kehamilan masa remaja, kecukupan zat gizi harus dipenuhi untuk pertumbuhan ibu muda dan bayi yang dikandungnya. Pada kondisi ini, remaja putri sangat rentan menderita KEK, anemia dan kurang zat gizi mikro antara lain besi dan seng, karena sering kali remaja putri ini memasuki masa kebamilannya dalam kondisi cadangan zat gizinya kurang atau terbatas ${ }^{(13)}$.

Kurang asupan zat besi dari makanan yang hanya sekitar 2/3 dari Angka Kecukupan Gizi (AKG) menjadi penyebab utama anemia di Indonesia ${ }^{(14)}$. Infeksi malaria dan cacing merupakan faktor yang memperberat kondisi anemia. Secara umum, anemia selalu dihubungkan dengan kekurangan zat besi. Kurang zat gizi mikro lain (protein, vitamin B12, vitamin A, Niasin dan Asam Folat) dan faktor genetik (talasemia) juga harus dipertimbangkan sebagai penyebab anemia( ${ }^{(8)}$. Data prevalensi kurang zinc pada remaja putri di Indonesia sangat terbatas, namun pada daerah dimana prevalensi anemia kurang besi tinggi, harus dipikirkan juga kemungkinan kurang zinc, karena sumber zat besi dan zinc dari makanan relative sama yaitu dari makan hewani ${ }^{(15)}$.

Berkenaan dengan masih banyaknya WUS termasuk ibu hamil yang berisiko KEK, anemia dan kurang zat gizi mikro lain (zinc), peningkatan status gizi lebih efektif bila dilakukan sedini mungkin, sebelum kehamilannya. Sejak 30 (tiga puluh) tahun yang lalu, suplementasi besi-folat pada ibu hamil telah dilaksanakan, namun menurut Survei Kesehatan Rumah Tangga.prevalensi anemia pada ibu hamil masih tinggi $(57,1 \%)$ ${ }^{(11)}$, Sementara upaya untuk meningkatkan status gizi terutama pada remaja putri sebagai calon ibu masih kurang mendapat perhatian. Mengingat bahwa remaja putri selain menderita anemia kemungkinan juga menderita kurang seng, menambahkan zinc pada suplementasi zat besi akan memberikan manfaat untuk meningkatkan kadar hemoglobin, serta meningkatkan status gizi remaja putri tersebut.

Ada interaksi negatif antara besi dan seng bila diberikan secara bersamaan, dimana seng menghambat besi dan sebaliknya besi menghambat seng(16). Zat besi dan seng yang sama-sama mempunyai ion (2+), akan berkompetisi dalam usus, satu sama lain akan menggangu penyerapan. Perbandingan dosis yang tepat masih menjadi perdebatan, namun Solomon 
M.

menganjurkan perbandingan zat besi/zinc tidak melebihi 2: $1^{(17)}$.

Oleh karena itu suplementasi zat besizinc dengan perbandingan yang tepat untuk menanggulangi anemia, perlu dilakukan. Diharapkan hasil penelitian ini dapat menjadi salah satu acuan dalam mengembangkan program perbaikan gizi, untuk mencapai Keluarga Sadar Gizi (KADARZI).

Penelitian ini bertujuan untuk mencari perbandingan yang tepat dari dua macam dosis suplementasi zat besi-zinc untuk menurunkan prevalensi anemia dan meningkatkan status gizi remaja putri.

\section{BAHAN DAN CARA}

\section{Desain,Lokasi dan Sampel Penelitian}

Penelitian Kabupaten Kupang, Provinsi Nusa Tenggara Timur (NTT). Sampel penelitian adalah murid wanita Sekolah Dasar yang berumur 10 - 12 tahun. Pada tahap awal dilakukan skrining dilakukan dan mendapatkan sample sebesar 134 orang. Sebelum suplementasi semua subyek minum obat cacing (dosis tunggal $500 \mathrm{mg}$ mebendazole), untuk menghindari pengaruh kecacingan pada anemia.. Satu minggu kemudian, subyek secara random dibagi menjadi 3 kelompok suplementasi Suplementasi dikonsumsi setiap hari selama $12 \mathrm{mg}$. Kelompok $1(n=44)$ minum zat besi sebesar $60 \mathrm{mg} / \mathrm{hari}$, kelompok $2 \quad(\mathrm{n}=44)$ minum zat besi/zinc dengan perbandingan 2 : 1; $30 \mathrm{mg}$ zat besi dan $15 \mathrm{mg}$ zinc/hari, kelompok $3 \quad(n=45)$ minum zat besi/zinc dengan perbandingan 4: 1; $60 \mathrm{mg}$ zat besi dan $15 \mathrm{mg}$ zinc/hari.

Setiap subyek menerima suplemen (dalam bentuk kapsul) selama 12 minggu berturut-turut, dan subyek minum suplemen di sekolah (jam 10.00 atau 13.00) diawasi oleh guru. Pada hari libur, subyek diminta minum suplemen dirumah yang dipastikan kembali pada hari berikutnya. Bila subyek absen, misalnya karena sakit, dilakukan kunjungan rumah agar tetap minum suplemen.

Pengumpulan data dilakukan setelah mendapat persetujuan dari Departemen Kesehatan RI, Dinas Kesehatan Provinsi
NTT dan Kota Kupang, serta Kepala Sekolah Dasar yang diteliti. Seluruh subyek dan orang tua nya setuju dengan menanda tangani surat persetujuan setelah mendapat penjelasan tentang prosedur penelitian

Penentuan kadar hemoglobin $(\mathrm{Hb})$ dilakukan dengan sampel darah kapiler dan ditentukan menggunakan metoda cyanmethemoglobin (Hemocue), dan subyek dinyatakan anemia bila kadar $\mathrm{Hb}<12$ $\mathrm{g} / \mathrm{dL}^{(18,19,20)}$.

Pengukuran antropometri dilakukan oleh tenaga ahli gizi terlatih mengikuti prosedur standar(21), untuk menentukan status gizi. Berat Badan (BB) ditimbang menggunakan "platform weighing Scale (770 alpha; SECA, Hamburg, Germany)" dengan ketepatan $0.1 \mathrm{~kg}$ dan Tinggi Badan (TB) diukur dengan "Microtoise" dengan ketepatan $0.1 \mathrm{~cm}$. Status gizi ditentukan dengan persentile dari Berat Badan menurut Umur (BB/U), Tinggi Badan menurut Umur (TB/U) dan Indeks MAsa Tubuh menurut Umur (IMT/U), merujuk pada CDC Growth Chart for the United States ${ }^{(22)}$

Subyek dikategorikan "normal" bila (IMT/U) berada diantara $5^{\text {th }}$ dan $<85^{\text {th }}$, Persentile, sedangkan "berat badan rendah" bila $(B B / U)$ Persentile $<3^{\text {th }}$, "pendek" bila $(T B / U)<3^{\text {th }}$ persentile, dan "kurus" bila $(\mathrm{IMT} / \mathrm{U})<5^{\text {th }}$ persentile.

\section{Pengolahan dana Analisa Data}

Perubahan kadar hemoglobin, BB, TB dan IMT/U didalam kelompok sebelum dan sesudah suplementasi, dianalisa dengan "Paired T-test". "Analysis of Variance (ANOVA)" dilakukan untuk melihat perbedaan kadar hemoglobin, BB, TB dan IMT/U antara kelompok pada awal dan akhir suplementasi. Tes Bonferroni dilakukan bila F-test berbeda secara bermakna.

Perubahan prevalensi anemia dan status gizi subyek didalam kelompok sebelum dan sesudah suplementasi, dianalisa dengan "McNemar test", sedangkan perbedaan status anemia antara kelompok dianalisa menggunakan "Pearson Chi-Square". 
M.

\section{HASIL}

\section{Karakteristik sampel_}

Subyek dalam penelitian ini berumur rata-rata 10,6 tahun, dan hanya 3 persen yang sudah haid. Umumnya subyek berasal dari keluarga kelas sosial dan ekonomi menengah kebawah. Pendidikan orang tua kebanyakan hanya lulus Sekolah Menengah Umum/SMU, yaitu sekitar 40 persen dan 8 persen sampai ke jenjang universitas/ akademik. Pekerjaan ayah umumnya Pegawai Negeri Sipil/PNS (41,3\%), sebagian kecil sebagai pedagang dan buruh lepas.
Sedangkan ibu sebagian besar tidak bekerja $(63 \%)$, dan kalau bekerja umumnya berdagang, menjadi PNS, dan ada juga yang menjadi Tenaga Kerja Indonesia (TKI). Mayoritas subyek berasal dari wilayah provinsi NTT (90\%), yaitu dari Pulau Timor (tempat Kota Kupang), Pulau Flores, Pulau Sumba, Pulau Alor, Pulau Rote dan pulaupulau kecil disekitarnya.

Kepatuhan subyek minum suplemen bagus, terlihat bahwa rata-rata subyek minum 82 dari 84 kapsul yang seharusnya diminum setiap hari selama 12 minggu. Pada akhir penelitian, 3 (tiga) orang subyek menolak untuk diambil darahnya.

Tabel 1

Kadar hemoglobin dan Berat Badan, Tinggi Badan, Indeks Masa Tubuh pada remaja putri sebelum dan sesudah suplementasi.

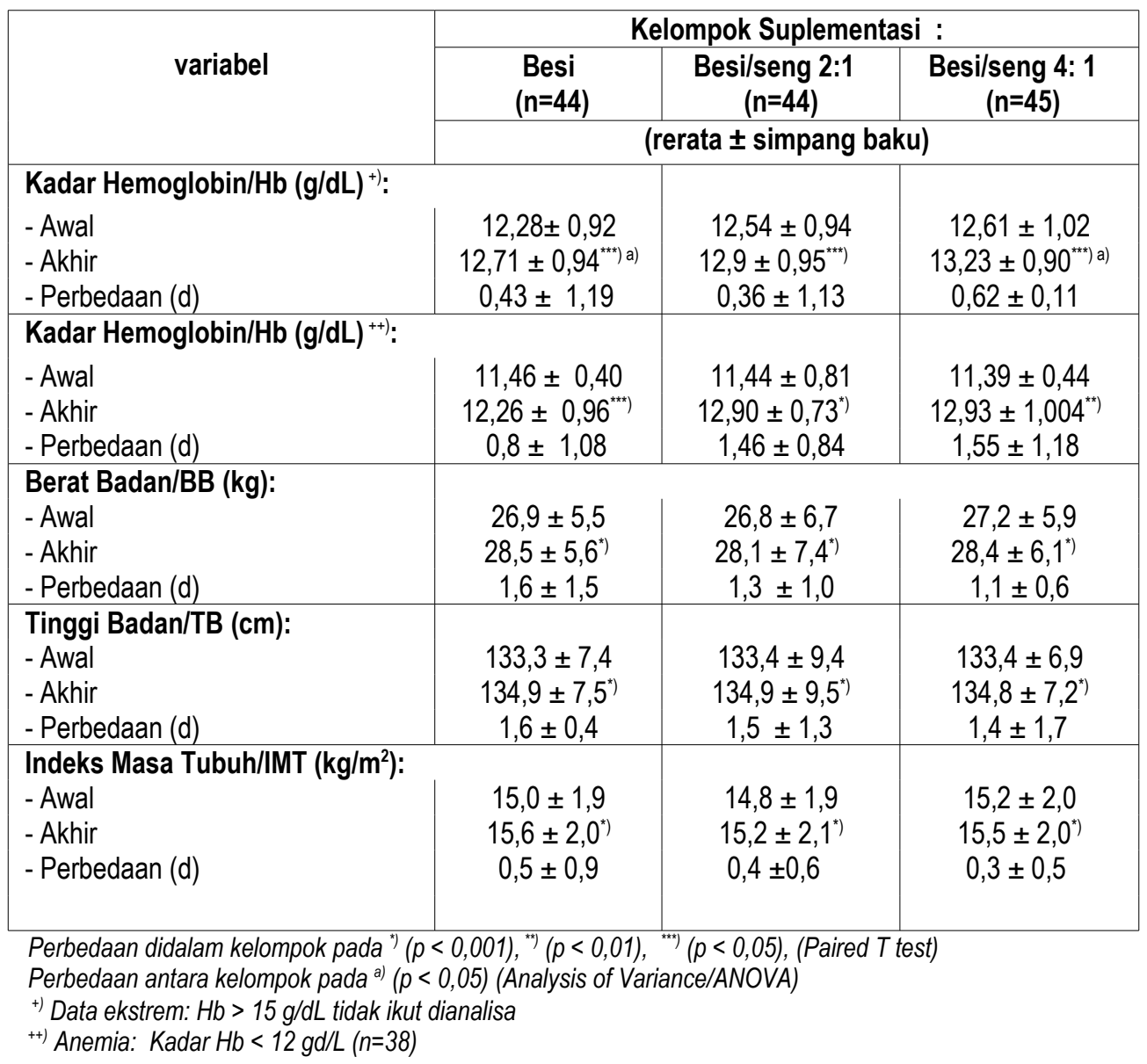


M.

Pada awal penelitian, kadar hemoglobin pada ketiga kelompok menunjukkan kadar yang sama, dengan rerata dan simpang baku 12,48 \pm 9,7 g/dL. Kadar hemoglobin meningkat secara bermakna $(p<0,05)$ di semua kelompok, menunjukkan bahwa pemberian suplementasi besi zat dengan atau tanpa zinc dapat meningkatkan kadar hemoglobin; pada kelompok 1 ( $\mathrm{d}=0,43 \mathrm{~g} / \mathrm{dL}$ ), kelompok 2 ( $\mathrm{d}=0,36 \mathrm{~g} / \mathrm{dL})$, dan kelompok 3 $(\mathrm{d}=0,62 \mathrm{gd} / \mathrm{L})$ (Tabel 1). Analisa statistik dengan ANOVA, menunjukkan bahwa subyek yang minum suplemen zat besi/zinc dengan perbandingan 4: 1, pada akhir suplementasi kadar hemoglobin nya lebih tinggi secara bermakna ( $p<0.05)$, dibandingkan dengan minum zat besi saja. Analisa lebih lanjut pada subyek anemia $(\mathrm{Hb}$ $<12 \mathrm{~g} / \mathrm{dL}$ ), pada awal penelitian nilai rerata dan simpang baku kadar hemoglobin adalah
$11,43 \pm 0,54 \mathrm{~g} / \mathrm{dL}$. Suplementasi zat besi dengan atau tanpa zinc meningkatkan kadar hemoglobin secara bermakna pada setiap subyek anemia; kelompok 1 ( $d=0,8 \mathrm{~g} / \mathrm{dL})$, kelompok 2 (d=1,46 g/dL) dan kelompok 3 $(\mathrm{d}=1,55 \mathrm{~g} / \mathrm{dL})$, yang tidak berbeda bila dibandingkan antar kelompok.

Pada akhir suplementasi, prevalensi anemia menurun secara bermakna ( $p<$ $0,05)$, dengan suplementasi besi dengan atau tanpa zinc, dari 29,1 persen menjadi 13,1 persen (Gambar 1). Analisa statistik dengan Pearson Chi Square, menunjukkan tidak ada perbedaan prevalensi anemia dengan pemberian ketiga jenis suplemen yang berbeda. Pada analisa setiap kelompok, ternyata suplementasi besi saja dapat menurunkan prevalensi anemia secara bermakna $(p<0,05)$, dari 36,4 persen menjadi 16,3 persen.

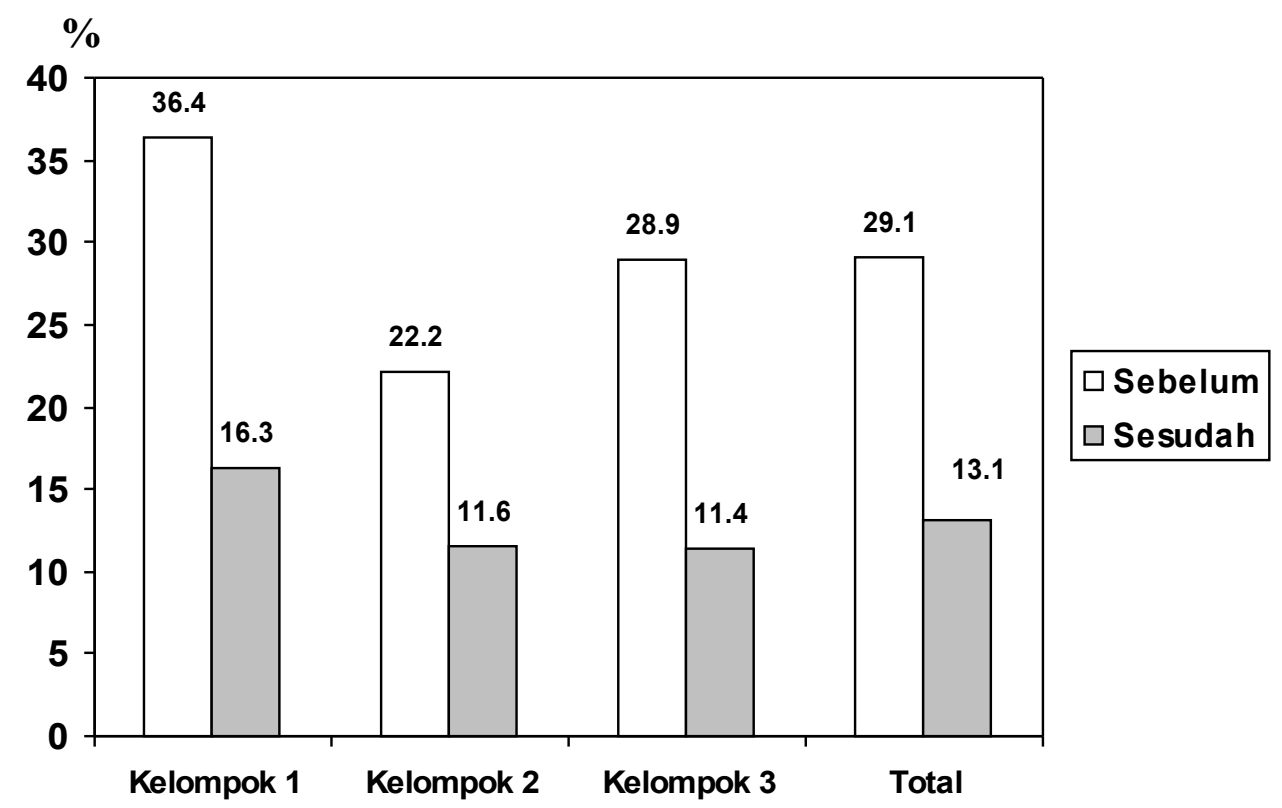

Gambar 1

Prevalensi anemia pada remaja putri sebelum dan sesudah suplementasi

Anemia; kadar $\mathrm{Hb}<120 \mathrm{~g} / \mathrm{L}$, Perbedaan didalam kelompok pada $(p<0,05)$, (McNemar test) 


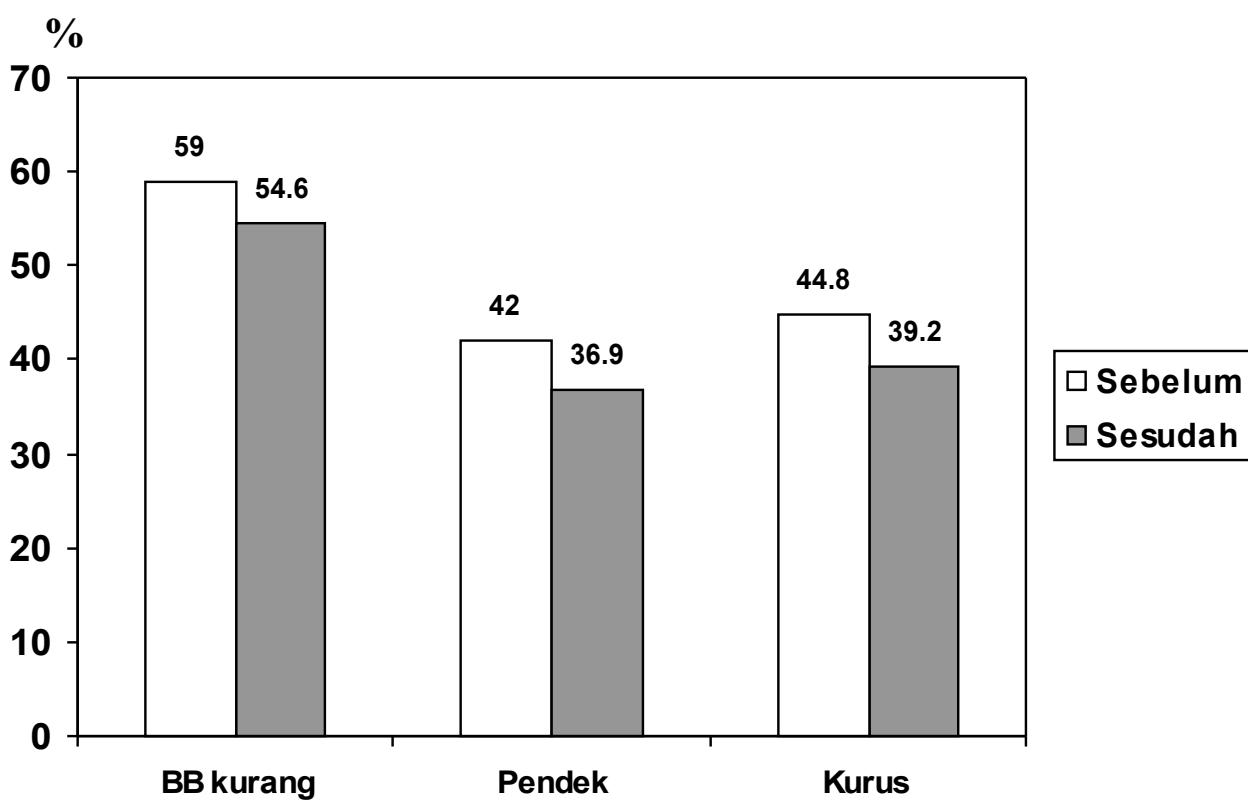

Gambar 2

Proporsi Berat Badan kurang, pendek dan kurus pada remaja putri sebelum dan sesudah suplementasi

D nulaily, DD U - -

Suplementasi zat besi/zinc dengan perbandingan 4: 1 atau 2: 1 juga meningkatkan Berat Badan, Tinggi Badan dan Indeks Masa Tubuh/umur secara bermakna, tetapi tidak ada perbedaan antara kelompok 2 dan kelompok 3, dan pada kedua kelompok zat besi/zinc tidak berbeda dengan kelompok 1 yang minum zat besi saja (Tabel 1).

Namun pada akhir suplementasi, proporsi subyek dengan Berat Badan Kurang $(54,6 \%)$, pendek $(36,9 \%)$ dan kurus $(39,2 \%)$.masih tinggi (Gambar 2).

\section{BAHASAN}

Pada penelitian ini, sebagian besar $(70,9 \%)$ remaja putri tidak anemia. Hasil penelitian menunjukkan remaja putri yang minum suplemen zat besi/zinc dengan perbandingan $4: 1$, kadar hemoglobin meningkat lebih tinggi dibanding dengan kadar hemoglobin remaja putri yang minum suplemen zat besi saja. Hal ini dapat dijelaskan bahwa pada subyek yang minum suplemen zat besi/zinc dengan perbandingan 4: 1, kadar hemoglobin nya meningkat secara bermakna $(p<0,05)$ dan lebih tinggi secara bermakna. Pada subyek yang minum suplemen zat besi/zinc dengan perbandingan $2: 1$, kadar hemoglobin nya meningkat secara bermakna $(p<0,05)$ dan cenderung lebih tinggi dibandingkan subyek yang hanya minum suplemen zat besi saja. Hasil yang senada pada remaja putri anemia, dimana subyek yang minum suplementasi zat besi/zinc dengan perbandingan $4: 1$ dapat meningkatkan kadar hempglobin cenderung lebih tinggi dari subyek yang hanya mendapatkan suplementasi zat besi saja. Analisa diatas menunjukkan bahwa kemungkinan sebagian penyebab anemia disini adalah kekurangan zat besi, dimana pemberian zat besi digunakan untuk membentuk hemoglobin. 
M.

Suplementasi zat besi saja dapat menurunkan prevalensi anemia secara bermakna ( $\mathrm{p} \quad 0,05)$. Walaupun suplementasi zat besi/zinc dapat meningkatkan kadar hemoglobin remaja putri lebih tinggi, namun penurunan prevalensi anemia tidak sebesar pada subyek yang hanya mendapatkan zat besi saja. Secara keseluruhan, prevalensi anemia menurun dengan suplementasi zat besi dengan atau tanpa zinc, dari 29,1 persen menjadi 13,1 persen pada akhir suplementasi, menunjukkan penambahan zinc pada suplementasi zat besi untuk suplementasi skepada remaja putri belum kelihatan manfaatnya untuk menurunkan prevalensi anemia.

Hasil ini agak berbeda dengan penelitian yang serupa, yang dilakukan di Kabupaten Tangerang, Provinsi Banten ${ }^{(7)}$, yang menemukan bahwa suplementasi zat besi/zinc dengan perbandingan $2: 1$ (30 mg zat besi dan 15 zinc mg/hari) pada remaja putri anemia selama 12 minggu meningkatkan status besi (termasuk kadar hemoglobin), serta menurunkan prevalensi anemia lebih baik dibanding dengan suplementasi besi saja (60 mg/hari) atau suplementasi zat besi/zinc dengan perbandingan $4: 1$ (60 $\mathrm{mg}$ zat besi dan $15 \mathrm{~m}$ zinc/hari). Penelitian ini juga menemukan bahwa penambahan zinc pada suplementasi besi, dapat mencegah pengaruh zat besi pada penurunan status zinc.

Pada penelitian ini perlu dicari faktor penyebab anemia, apakah kekurangan zat besi, protein, asam foalt, niasin dan faktor lain seperti infeksi malaria dan faktor genetik seperti talasemia. (NTT termasuk salah satu daerah endemik malaria). Pemeriksaan status besi yang lain seperti serum feritin, transferin receptor, zinc protoporphyrin perlu dilakukan, selain pemeriksaan kadar zinc, untuk melihat pengaruh supelementasi pada kadar zinc.

Pada penelitian ini, belum terlihat manfaat suplementasi zat besi/zinc untuk meningkatkan pertumbuhan remaja putri. Walaupun suplementasi zat besi/zinc dengan perbandingan $4: 1$ atau 2: 1 dapat meningkatkan Berat Badan, Tinggi Badan dan Indeks Masa Tubuh/umur secara bermakna, namun pada akhir suplementasi, proporsi subyek kurang gizi dimana subyek dengan Berat Badan Kurang, pendek dan kurus masih tinggi. Besi dan seng sangat penting untuk pertumbuhan fisik dan kematangan remaja putri ${ }^{(13)}$.

Tampaknya suplementasi zat besi dengan atau tanpa zinc selama 12 minggu belum cukup untuk menurunkan proporsi kurang gizi pada remaja putri. Menurut WHO, 1995 waktu yang tepat untuk mememacu pertumbuhan pada remaja putri adalah masa sebelum haid atau sekitar umur 12,8 tahun $^{(23)}$. Selain zat besi dan seng dari makanan, remaja putri dalam masa pertumbuhan memerlukan energi, protein, lemak dan zat gizi mikro (vitamin mineral) lain seperti kalsium, phosphor ${ }^{(13)}$, sehingga suplementasi zat besi/zinc untuk remaja putri, sebaiknya juga disertai suplementasi makanan yang cukup dan merupakan faktor membantu penyerapan besi dan zinc. Makanan hewani daging, ayam dan sayuran hijau kaya akan zat besi, sementara sumber makanan laut (ikan, udang cumi, kerang2an) tinggi tinggi kandungan zincnya.

\section{KESIMPULAN DAN SARAN}

Anemia merupakan masalah kesehatan pada remaja putri di Kota Kupang, Provinsi NTT, suplementasi zat besi dengan atau tanpa zinc selama 12 minggu dapat menurunkan prevalensi anemia. Suplementasi zat besi/zinc dengan perbandingan 4: 1, merupakan perbandingan yang tepat untuk meningkatkan kadar hemoglobin, namun suplementasi zat besi/zinc dengan perbandingan $2: 1$, dapat meningkatkan kadar hemoglobin remaja putri yang anemia. Suplementasi zat besi/zinc selama 12 minggu belum terlihat pengaruhnya pada percepatan pertumbuhan tinggi badan.

Studi kohort dalam skala luas dianjurkan melalui Usaha Kesehatan Sekolah di sekolah dasar, untuk meneliti perbedaan efek suplementasi besi/seng dengan perbandingan 4 : 1 dan perbandingan 2 : 1 pada status besi, zinc dan pola pertumbuhan remaja putri. 


\section{RUJUKAN}

1. Permaesih D, Pambudi D, Ridwan E. Laporan status gizi remaja dan faktor yang mempengaruhinya. Pusat Penelitian dan Pengembangan Gizi dan Makanan, Badan Penelitian dan Pengembangan Kesehatan, Departemen Kesehatan, 2003.

2. Dinas Kesehatan Kabupaten Tangerang. Laporan pelaksanaan kegiatan penanggulangan anemia di Sekolah Dasar Kabupaten Tangerang, 2001.

3. Soekarjo DD, Pee SD, Bloem MW, Tjiong $R$, Yip R, Schreurs, Muhilal. Socio-economic status and puberty are the main factors are determining anemia in adolescent girls and boy in East Java, Indonesia. Eur J of Clin Nutr 2001; 55: 32-39.

4. Permaesih D dkk. Status gizi dan status besi remaja putri di pesantren, Pusat Penelitian dan Pengembangan Gizi dan Makanan, 1988.

5. Lestari, Basuki S. Faktor-faktor yang berhubungan dengan kejadian Anemia gizi remaja putri Sekolah Menengah Umum di Kabupaten Bandung, Thesis Paska Sarjana Fakultas Kesehatan Masyarakat-Universitas Indonesia, 1996.

6. Angeles-Agdeppa I, Schulthink W, Sastroamidjojo S, Gross R and Karyadi D. Weekly micronutrient supplementation to build iron stores in female Indonesia adolescents. Am J Nutr 1997; 66: 177-183.

7. Indriastuti Kurniawan YA, Muslimatun S, Achadi EL and Sastroamidjojo S. Anaemia and iron deficiency anaemia among young adolescent girls from peri urban coastal area of Indonesia. Asia Pac J Clin Nutr 2006; 15 (3): 1- 6.

8. A UNICEF/UNU/WHO/MI Technical Workshop. Preventing Iron Deficiency in Women and Children, Technical
Consensus on Key Issues, New York, 1998.

9. Survei Kesehatan lbu Anak (SKIA), 2001. Dalam: Departemen Kesehatan RI. Program penanggulangan anemia gizi pada wanita usia subur, 2001. hal. 1-21.

10. Cousins RJ. Zinc. In: Ekhard EZ, Filer LJ. Jr Editor, Present knowledge in nutrition, $7^{\text {th }}$ ed, ILSI Press, Washington DC, 1996. p. $293-302$.

11. Survei Sosial Ekonomi Nasional, 1999.

12. Departemen Kesehatan RI. Laporan survei data dasar: Program penanggulangan anemia gizi pada wanita usia subur (Remaja putri dan Calon pengantin wanita) di Propinsi Jawa Tengah dan Jawa Timur, 1998/1999. hal. 25.

13. Spear B. Adolescent growth and development. In Vaughn IR, editors. Adolescent nutrition, Assessment and Management. Division of Pediatric and Adolescent Gynecology, University of Texas, Medical Branch at Galveston, Chapman \& Hall, Series in Clinical Nutrition, 1995. p. 3-20.

14. Husaini MA,Suharno D, Husaini YK, Siagian UL. Study nutritional anemia an assessment of information compilation for supporting and formulating national policy program, collaboration between Ministry of Health and WHO, and 1989.

15. Gibson RS, Ferguson EL. An interactive 24-hour recall for assessing the adequacy of iron and zinc intakes in developing countries. ILSI Press, USA, 1999. p. 48-60, 120-125.

16. Yadrick MK, Kenney MA, Winterfeldt EA. Iron, copper and zinc status: Response to supplementation with zinc or zinc and iron in adult females. A J Clin Nutr 1989; 49: 145-50.

17. Solomons NW. Physiological interaction of minerals in nutrient interactions. In Bodwell CE and Erdman JW, Jr. editors. Basic symposium series: Nutrition 
interaction, New York, USA, 1988. p. $127-132$.

18. Dallman PR, Locker AC, Johnson CL, Carroll M. Influence of age on laboratory criteria for the diagnosis of iron deficiency anemia and Iron deficiency in infants and children. In: Halberg $L$, Asp NG editors. Iron nutrition in health and disease. The Swedish Nutrition Foundation $20^{\text {th }} \quad$ International Symposium. John Libby and Co. Ltd, London, England, 1996. p. 65-74.

19. Sauberlich HE. Laboratory test for the assessment of nutritional status. $2^{\text {nd }} \mathrm{ed}$. Florida: CRC Press, 1999. p. 344-350, 384-390, 450.

20. Yip R, Parvanta I, Cogswell ME, McDonnell SM, Bowman BA, GrummerStrawn LM et al. Recommendations to prevent and control Iron Deficiency in the United stated. CDC, Atlanta, Georgia 30333, 1998.
21. Gibson RS. Principles of nutritional assessment, Oxford University Press, 1990. p.172-181.

22. Department of Health and Human Services CCDC-P-NCHS. Vital and Health Statistics, 2000. CDC Growth chart for the United States: Methods and development, data from the National Health and Nutrition Examination Surveys (NHANES), 2002.

23. WHO Technical Report Series 854. Physical Status; The use and interpretation, Report of a WHO Expert Committee. Geneva, 1995. p. 276-278. 